NASA/TM-2002-211724

\title{
Electrical Performance of the International Space Station U.S. Photovoltaic Array During Bifacial Illumination
}

Ann M. Delleur and Thomas W. Kerslake

Glenn Research Center, Cleveland, Ohio 
Since its founding, NASA has been dedicated to the advancement of aeronautics and space science. The NASA Scientific and Technical Information (STI) Program Office plays a key part in helping NASA maintain this important role.

The NASA STI Program Office is operated by Langley Research Center, the Lead Center for NASA's scientific and technical information. The NASA STI Program Office provides access to the NASA STI Database, the largest collection of aeronautical and space science STI in the world. The Program Office is also NASA's institutional mechanism for disseminating the results of its research and development activities. These results are published by NASA in the NASA STI Report Series, which includes the following report types:

- $\quad$ TECHNICAL PUBLICATION. Reports of completed research or a major significant phase of research that present the results of NASA programs and include extensive data or theoretical analysis. Includes compilations of significant scientific and technical data and information deemed to be of continuing reference value. NASA's counterpart of peerreviewed formal professional papers but has less stringent limitations on manuscript length and extent of graphic presentations.

- TECHNICAL MEMORANDUM. Scientific and technical findings that are preliminary or of specialized interest, e.g., quick release reports, working papers, and bibliographies that contain minimal annotation. Does not contain extensive analysis.

- CONTRACTOR REPORT. Scientific and technical findings by NASA-sponsored contractors and grantees.
- CONFERENCE PUBLICATION. Collected papers from scientific and technical conferences, symposia, seminars, or other meetings sponsored or cosponsored by NASA.

- SPECIAL PUBLICATION. Scientific, technical, or historical information from NASA programs, projects, and missions, often concerned with subjects having substantial public interest.

- TECHNICAL TRANSLATION. Englishlanguage translations of foreign scientific and technical material pertinent to NASA's mission.

Specialized services that complement the STI Program Office's diverse offerings include creating custom thesauri, building customized data bases, organizing and publishing research results ... even providing videos.

For more information about the NASA STI Program Office, see the following:

- Access the NASA STI Program Home Page at http://www.sti.nasa.gov

- E-mail your question via the Internet to help@sti.nasa.gov

- Fax your question to the NASA Access Help Desk at 301-621-0134

- Telephone the NASA Access Help Desk at 301-621-0390

- Write to:

NASA Access Help Desk

NASA Center for AeroSpace Information 7121 Standard Drive

Hanover, MD 21076 
NASA/TM-2002-211724

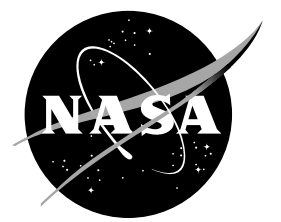

\section{Electrical Performance of the International Space Station U.S. Photovoltaic Array During Bifacial Illumination}

Ann M. Delleur and Thomas W. Kerslake

Glenn Research Center, Cleveland, Ohio

Prepared for the

37th Intersociety Energy Conversion Engineering Conference sponsored by the Institute of Electrical and Electronics Engineers, Electron Devices Society

Washington, DC, July 28-August 2, 2002

National Aeronautics and

Space Administration

Glenn Research Center 


\section{Acknowledgments}

The authors wish to thank Jeffrey S. Hojnicki for his help with code development; Anthony Jannette for maintaining the on-orbit operations summary; all the other members of the ISS EPS Analysis Team at GRC for their assistance; and Lou Ignaczak, Dave McKissock, and Bruce Manners for their reviews.

Available from

NASA Center for Aerospace Information 7121 Standard Drive

Hanover, MD 21076
National Technical Information Service 5285 Port Royal Road Springfield, VA 22100

Available electronically at http://gltrs.grc.nasa.gov/GLTRS 


\title{
ELECTRICAL PERFORMANCE OF THE INTERNATIONAL SPACE STATION U.S. PHOTOVOLTAIC ARRAY DURING BIFACIAL ILLUMINATION
}

\author{
Ann M. Delleur and Thomas W. Kerslake \\ National Aeronautics and Space Administration \\ Glenn Research Center \\ Cleveland, Ohio 44135 \\ Phone: 216-433-5519 \\ Fax: 216-433-2995 \\ ann.delleur@grc.nasa.gov \\ Thomas.w.kerslake@grc.nasa.gov
}

\begin{abstract}
With the first United States (US) photovoltaic array (PVA) activated on International Space Station (ISS) in December 2000, on-orbit data can now be compared to analytical predictions. Due to ISS operational constraints, it is not always possible to point the front side of the arrays at the Sun. Thus, in many cases, sunlight directly illuminates the backside of the PVA as well as albedo illumination on either the front or the back. During this time, appreciable power is produced since the solar cells are mounted on a thin, solar transparent substrate. It is important to present accurate predictions for both front and backside power generation for mission planning, certification of flight readiness for a given mission, and on-orbit mission support. To provide a more detailed assessment of the ISS power production capability, the authors developed a PVA electrical performance model applicable to generalized bifacial illumination conditions. On-orbit PVA performance data were also collected and analyzed. This paper describes the ISS PVA performance model, and the methods used to reduce orbital performance data. Analyses were performed using SPACE, a NASAGRC developed computer code for the ISS program office. Results showed a excellent comparison of onorbit performance data and analytical results.
\end{abstract}

\section{INTRODUCTION}

The ISS is a complex spacecraft that will take several years to assemble in orbit. With the first United States photovoltaic array launched, installed, and activated on flight 4A (early December 2000), the on-orbit data can now be compared to analytical predictions derived from the authors' previously published work on back-illuminated performance modeling (Delleur, Kerslake, et al., 1999) and albedoenhanced performance modeling (Kerslake and Hoffman, 1997, 1999). A photograph of the US PVAs (2B and 4B) on ISS is shown in Figure 1.

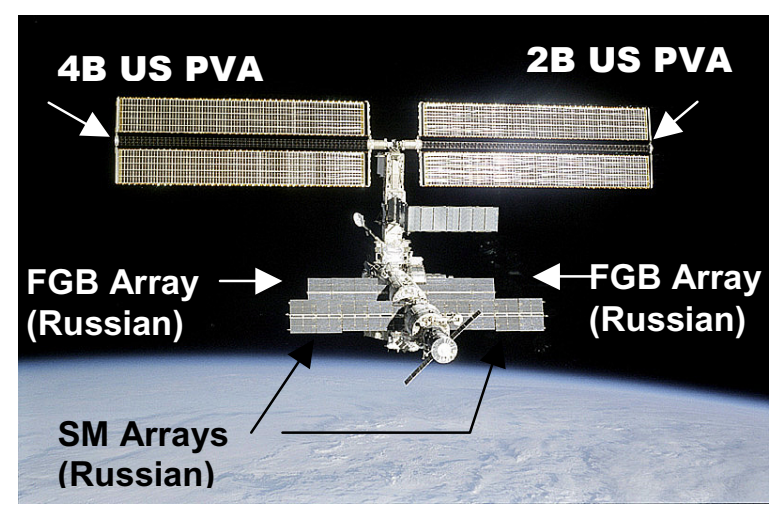

FIGURE 1. - ISS AFTER SHUTTLE SEPARATION, UF-1 MISSION

Close-up photographs of the PVA wings after deployment were taken and are shown in Figures 2 and 3. From a power perspective, it is best to point the front side of the arrays at the sun. However, several operational scenarios require that the arrays be held fixed and thus the sun can directly illuminate the backside of the large US solar arrays. For example, the US ISS arrays are held stationary to minimize plume impingement from the space shuttle during docking and undocking as well as during shuttle wastewater dumps. In addition, many 
assembly and maintenance procedures also require that the arrays be held at fixed position for hours, which can significantly reduce power generation.

During the portions of the orbit when the backside is directly illuminated by the sun, appreciable power (about $1 / 3$ rd of front side power) is produced since the solar cells are mounted on a thin, solar transparent polymer substrate. Figure 3 shows the backside of PVA panels containing seriesconnected, $8 \mathrm{~cm}$ by $8 \mathrm{~cm}$ crystalline silicon solar cells with gridded back contacts and copper flat printed circuit interconnects (Vogt and Proeschel, 1988, Hashmi, 1993, Lillington, et al., 1988).

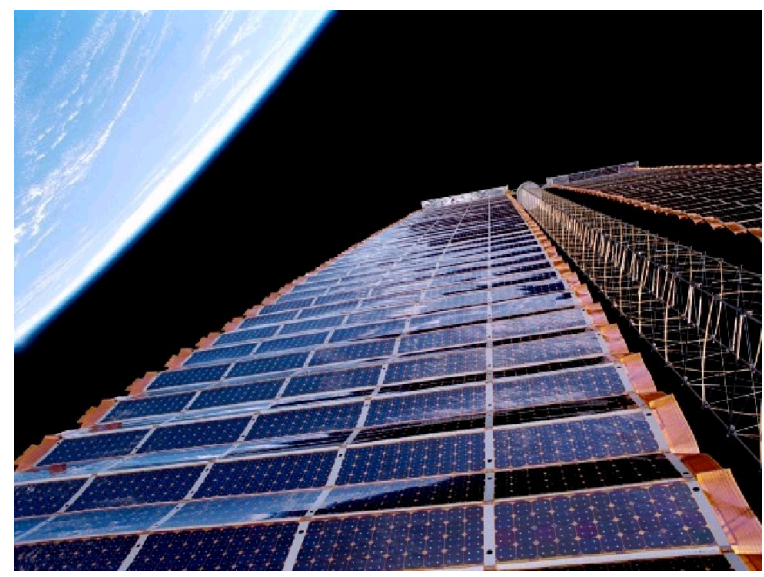

FIGURE 2. - ISS PHOTOVOLTAIC ARRAY WING (FRONT SIDE)

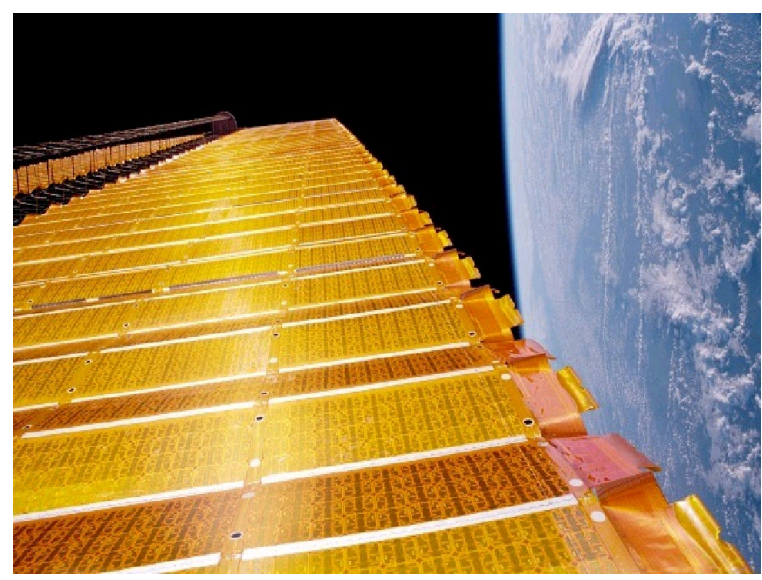

FIGURE 3. - ISS PHOTOVOLTAIC ARRAY WING (BACKSIDE)

It is important to present accurate power generation predictions for mission planning, certification of flight readiness, and on-orbit mission support. Assessments of ISS electric power system performance have been performed by NASA Glenn Research Center using the code SPACE (System Power Analysis for Capability Evaluation) (Hojnicki, et al., 1993; Fincannon, et al., 1996, and Kerslake, et al., 1993). SPACE has recently been validated with on-orbit data as described in a companion paper (Jannette, et al., 2002).

To provide a more detailed assessment of the ISS power production capability, engineers at the NASA Glenn Research Center (GRC) collected and reduced ISS PVA orbital performance data during backside direct solar and Earth albedo illumination conditions. These data were compared with analytical predictions from the latest, bifacial PVA performance model, implemented in SPACE. This paper describes the methods used to process on-orbit data, the improved ISS PVA performance model and the results from comparing SPACE analytical predictions with PVA orbital performance data.

\section{PVA TELEMETRY AND DATA PROCESSING}

Orbits that had a significant portion of direct backside solar illumination with little to no shadowing were considered optimal for analysis. At moderate to high solar beta angles (the angle between the SunEarth line and the orbit plane), significant shadowing of the arrays by the station structure or the shuttle occur. Since shadowing can reduce the number of active strings, recreating the available array current can be done with a shadowing factor, but for ease of analysis, orbits without shadowing were desired. Sun tracking the front side is the normal solar array operation, thus to have backside illumination with no shadowing, orbits with unusual array pointing at low solar beta angles were investigated. Once a possible time period was identified, the data was put through two tests to determine if there was indeed backside illumination as well as a sufficient time span of backside illumination to be useful for analysis. For the first test, the total array current (IPVA) was plotted to determine if there were any periods where the current peak did not exceed $80 \mathrm{~A}$, the maximum current output for backside illumination (Delleur, Kerslake, et al., 1999). If a candidate day passed the peak current test, then a second test on the data was needed to determine if the array was receiving significantly off-pointed, front side illumination or direct solar backside illumination.

By converting the on-orbit telemetry for vehicle attitude and array orientation in to SPACE inputs, SPACE was run to generate station orientation and array view factors through the orbit to the Sun, Earth, albedo, etc. If the array view factor showed direct solar illumination on the backside and the vehicle orientation through the orbit did not cause shadowing in the array, then the data was deemed acceptable for further study.

On December 10, 2001, during mission UF-1, the shuttle astronauts installed thermal blankets on both array gimbals during a 4-hour space walk. The arrays were parked $125^{\circ}$ apart to allow astronaut access, and optimize power generation. With the arrays fixed in this orientation, the starboard array, designated 2B, was solar illuminated on the front side for the first part of the orbit, then back illuminated. The 4B array, the port side array, observed the reverse, backside 
illumination first then front. The results for $2 \mathrm{~B}$ and $4 \mathrm{~B}$ were similar.

The second illustrated occurrence of backside illumination came from a crew sleep period on February 2, 2002, during an otherwise uneventful day.

The final occurrence of low solar beta backside illumination illustrated in this paper was taken from April 12, 2002, during the $8 \mathrm{~A}$ mission with the shuttle docked, to install a major truss segment. The angle at which the 4B array was parked, resulted in direct backside illumination during the first half of the orbit. Though the array was parked for many days, for proposes of illustration only one typical orbit is needed. Other relevant information for these mission days is summarized in Table 1 below.

\begin{tabular}{|c|c|c|c|}
\hline \multicolumn{4}{|c|}{ On-Orbit Data } \\
\hline Year & 2001 & 2002 & 2002 \\
\hline Day & 344 & 33 & 102 \\
\hline Date & 10 Dec 01 & 02 Feb 02 & 12 Apr 02 \\
\hline Stage & $\begin{array}{c}\text { UF-1 } \\
\text { Mission/ } \\
\text { Shuttle } \\
\text { Docked }\end{array}$ & $\begin{array}{l}\text { UF-1 Stage/ } \\
\text { Station } \\
\text { Alone }\end{array}$ & $\begin{array}{c}\text { 8A Mission/ } \\
\text { Shuttle } \\
\text { Docked }\end{array}$ \\
\hline 4B PVA & Parked & Parked & Parked \\
\hline 2B PVA & Parked & $\begin{array}{c}\text { Sun } \\
\text { Tracking }\end{array}$ & $\begin{array}{c}\text { Sun } \\
\text { Tracking }\end{array}$ \\
\hline $\begin{array}{c}\text { Solar } \beta \\
\text { Angle }\end{array}$ & $1.5^{\circ}$ & $24.2^{\circ}$ & $8.3^{\circ}$ \\
\hline $\begin{array}{c}\text { Solar Flux } \\
\left(\mathrm{W} / \mathrm{m}^{2}\right)\end{array}$ & 1414.2 & 1371.3 & 1364.6 \\
\hline Event & $\begin{array}{l}\text { EVA to install } \\
\text { thermal } \\
\text { blankets } \\
\text { around the } \\
\text { solar array } \\
\text { gimbals }\end{array}$ & $\begin{array}{l}\text { Crew Pre- } \\
\text { Sleep }\end{array}$ & Crew Sleep \\
\hline
\end{tabular}

\section{Data Processing}

The PVA performance is measured by the Sequential Shunt Unit (SSU) currents and voltage. When the array produces more power than is needed to meet the load current and battery charge current demand, excess array current is shunted in the SSU. A useful measure of PVA performance is the total available current production, IPVA, given by:

$$
I_{P V A}=I_{S S U}+F_{\text {corr }}{ }^{*} I_{\text {shunt }}+I_{\text {supply }} \text {, }
$$

where Issu is the SSU output current, $I_{\text {shunt }}$ is the SSU shunt current, $I_{\text {supply }}$ is the SSU power supply current (0.4-amps) and $F_{\text {corr }}$ is a correction factor $(0.915)$ to estimate equivalent operating current based on the measured shunt current. $F_{\text {corr }}$ accounts for: (a) the shift from shunt current (near short-circuit current) to operating current (near peak power point current), (b) current-voltage (IV) operating point to accommodate voltage drops in the cell interconnects, power harness/cabling, and SSU shunt element and (c) the shift in operating temperature $\left(\sim 5^{\circ} \mathrm{C}\right)$ between a shunted and operating solar cell string. If necessary, a string shadowing correction factor can also be calculated using SSU shunt circuit control telemetry and calculated PVA shadow patterns. Shadowed PVA current output results are discussed elsewhere (Fincannon, 2002). The measurement error is $+0 \%$ / $1 \%$ and $+0 \% /-3 \%$ for SSU output current and shunt current, respectively.

\section{PVA PERFORMANCE MODEL}

\section{Direct Illumination}

The solar cell IV curve during front or back illumination was modeled with cell current, I, as an exponential function of operating voltage, $\mathrm{V}$ (Josephs, 1976):

$$
\begin{aligned}
& I=I s c-10^{*}\left[\exp \left\{q^{*}\left(V-I^{*} R s\right) / \gamma^{*} k^{*} T\right\}-1\right]-V / R s h,(2) \\
& \text { with } \\
& \gamma \quad=\text { curve fitting parameter } \\
& \mathrm{I}=\text { cell current } \\
& \mathrm{k}=\text { Boltzmann constant } \\
& \text { lo = cell diode saturation current, 5.8E-09 A } \\
& \mathrm{q}=\text { electron unit charge } \\
& \mathrm{Rs}=\text { cell series resistance } \\
& \text { Rsh }=\text { cell shunt resistance } \\
& \mathrm{T}=\text { cell absolute temperature } \\
& \mathrm{V}=\text { cell voltage }
\end{aligned}
$$

The cell shunt resistance was assumed to be very large so that the V/Rsh term vanishes. The unknown terms of this equation, lo, Rs, and $\gamma$ were determined based on the instantaneous values of cell front side short-circuit current (Isc), open-circuit voltage (Voc), maximum power point current (Imp) and maximum power point voltage (Vmp). For solar illuminated front side performance, instantaneous values were based on averaged, measured values obtained during front side flash testing. These values were then corrected for orbital degradation factors, operating temperature, and solar pointing conditions.

For backside solar illuminated performance, the cell IV values were originally based on backside flash test measurements over a range of incidence angles (Delleur, Kerslake, et al., 1999). These backilluminated cell IV values were normalized by normalincidence front side cell IV values. The normalized values were then multiplied by the instantaneous front side cell IV values to obtain the instantaneous backside values.

In the current work, the backside performance model was improved. The backside (subscript b) Voc values were used as measured, as a function of incidence angle, $\theta$. Other backside values were determined as follows:

$$
\begin{array}{ll}
I S c_{b} & =I s c{ }^{*} I r * \cos \theta \\
I m p_{b} & =I m p * I^{*} \cos \theta \\
V m p_{b} & =V m p+R s^{*}\left(I s c-I s c_{b}\right)
\end{array}
$$

where Ir is the ratio of measured front side Isc divided by the measured backside Isc at normal incidence. 


\section{Albedo Illumination}

Solar cell front or back albedo (subscript a) illuminated cell IV values were determined by scaling currents by the ratio of Earth albedo flux intensity to solar insolation flux and by adjusting voltages with current levels as follows:

$$
\begin{aligned}
& \text { Isc } \mathrm{Ia}_{\mathrm{a}} \quad=\text { Isc * Albedo / Insolation } \\
& \mathrm{Voc}_{\mathrm{a}} \quad=\mathrm{Voc}^{*} \operatorname{In}\left(\mathrm{Isc}_{\mathrm{a}} / \mathrm{lo}\right) / \ln \text { (Isc/lo) } \\
& V m p_{a}=V m p+R s^{*}\left(I s c-I s c_{a}\right) \\
& \operatorname{Imp}_{\mathrm{a}} \quad=\operatorname{Imp} \text { * Albedo / Insolation + } \\
& \mathrm{dl} /\left.\mathrm{dV}\right|_{\mathrm{mp}}{ }^{*}\left(\mathrm{Vmp} \mathrm{p}_{\mathrm{a}}-\mathrm{Vmp}\right)
\end{aligned}
$$

In these scaling relationships, based on Josephs (1976), the small performance impacts of albedo spectral and directional distributions were ignored. The small illumination contribution from ISS surface albedo was also ignored.

\section{Bifacial Illumination}

For generalized PVA illumination, there will be a direct solar component from the front or the back, and albedo components on the PVA front and/or back. The solar cell bifacial (subscript bf) IV values were calculated by superposing currents and scaling voltages with currents. Superposition was allowed due to the linear partial differential equations that describe the diffusion of electrons and holes in the solar cell junction (Bordina, 1992). The resulting equation set, formulated for front side direct solar illumination, were:

$$
\begin{aligned}
& I s C_{b f}=I s c+I s C_{a}+I s C_{a b} \\
& V_{o c_{b f}} \quad=V_{o c}{ }^{*} \operatorname{In}\left(I \mathrm{IS}_{\mathrm{bf}} / \mathrm{lo}\right) / \ln (\mathrm{Isc} / \mathrm{lo}) \\
& \mathrm{Vmp}_{\mathrm{bf}} \quad=\mathrm{Vmp}+\mathrm{Rs}^{*}\left(\mathrm{Isc}_{\mathrm{bf}}-\mathrm{Isc}\right) \\
& I \mathrm{Impf}_{\mathrm{bf}} \quad=\mathrm{Imp}{ }^{*} I \mathrm{Isc}_{\mathrm{bf}} / \mathrm{Isc}+ \\
& \mathrm{dl} /\left.\mathrm{dV}\right|_{\mathrm{mp}}{ }^{*}\left(\mathrm{Vmp}-\mathrm{Vmp} \mathrm{pf}_{\mathrm{bf}}\right)
\end{aligned}
$$

Once the bifacial solar cell IV curve was obtained, the solar cell string IV curve was calculated by summing the voltage contribution of the individual series-connected cells and subtracting the voltage drop in cell interconnects, string power harness/cabling, blocking diode, and SSU internal resistance. String current was iteratively determined such that cell voltage generation less line voltage loss satisfied the SSU output voltage set point. In the presence of string shadowing, separate IV curves were calculated for shadowed and unshadowed string sections. In satisfying the SSU output voltage set point, three outcomes were possible for shadowed string current: (1) unshadowed cells provided all the string current and voltage while shadowed cells were isolated with forward operating by-pass diodes, (2) shadowed cells (with albedo illumination) currentlimited all string solar cells and unshadowed and shadowed cells provided the string voltage, and (3) the string current was zero due to insufficient voltage generation to meet the SSU output set point voltage. Total PVA current capability was obtained by summing the current contribution of individual strings.

Based on analysis methods and data input uncertainties, the estimated uncertainty in calculated
PVA current is $\pm 5 \%$. Based on the short-term uncertainty in Earth albedo and infrared emission, the estimated uncertainty in short-term PVA current is $\pm 3 \%$ for a Sun tracking orbit. Therefore, the total rootsum-squared uncertainty in calculated PVA current is $\pm 6 \%$.

\section{PVA PERFORMANCE COMPARISONS}

PVA back-illuminated performance data can be obtained when the solar tracking beta gimbal is locked. The Sun vector sweeps over a range of incident angles on the PVA front and back sides. This situation did occur on December 10, 2001, during extravehicular operations. The measured and calculated values of PVA current capability is shown in Figure 4 for the orbital Sun period of one such orbit. At the start of the Sun period (16.1 hours), the 4B PVA backside is nearly normal to the Sun vector. By 16.5 hours, the ISS has moved through the orbit to place the 4B PVA edge-on to the Sun vector. Nearing the end of the Sun period (16.85 hours), the 4B PVA is now oriented with near normal solar pointing on the array front side.

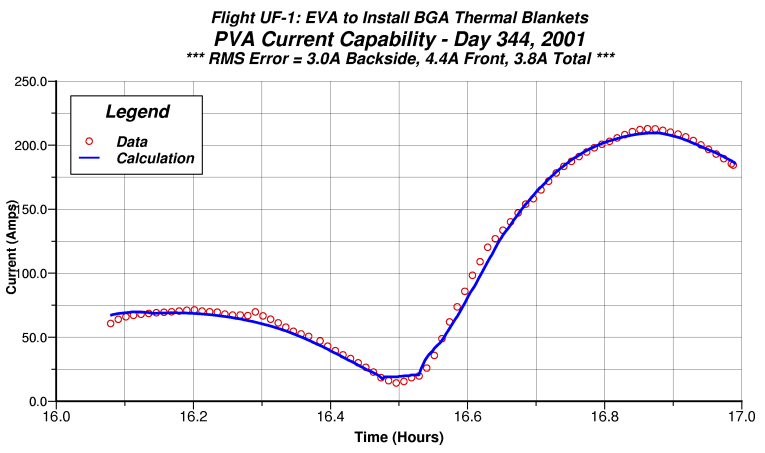

FIGURE 4. - COMPARISON OF PREDICTED AND MEASURED PVA CURRENT PRODUCTION CAPABILITY (DEC 10, 2001)

The qualitative comparison between measured and calculated PVA currents through the orbit Sun period is excellent. Quantitatively, the root-meansquare (RMS) difference between measured and calculated values was $3.0 \mathrm{~A}$ on the back and $4.4 \mathrm{~A}$ on the front. This is equivalent to approximately $2 \%$ of PVA front side current capability or $4 \%$ of PVA backside current capability. Front-illuminated current data are smooth and in good agreement with calculated values. Minor discrepancies in backside calculated versus measured currents are discussed in the next section.

The 4B PVA was also locked for several orbits on April 12, 2002. Measured and calculated values of PVA current capability are shown in Figure 5 for the Sun period of one orbit.

An excellent qualitative comparison exists between measured and calculated PVA current values. The RMS difference between measured and calculated values were $2.4 \mathrm{~A}$ on the backside and 5.0A on the front side. Compared to data from 
December 10, 2001, these data are smoother during backside illumination (5.45 hours to 5.75 hours), but show more variation during front side illumination (5.75 hours to 6.40 hours).

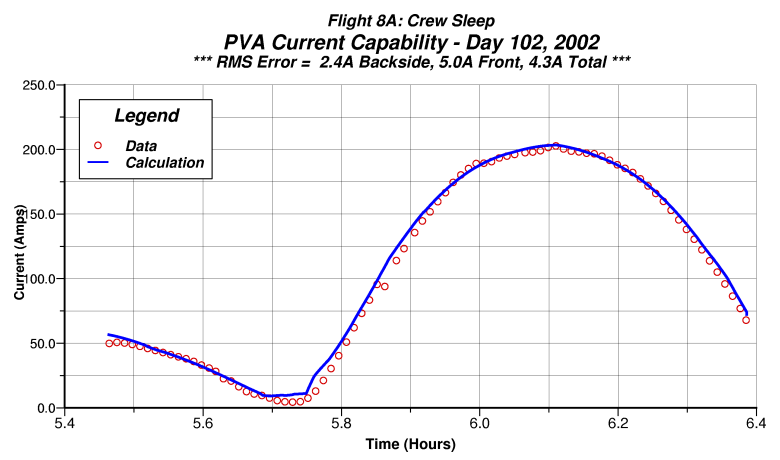

FIGURE 5. - COMPARISON OF PREDICTED AND MEASURED PVA CURRENT PRODUCTION CAPABILITY (APRIL 12, 2002)

The last comparison of PVA current capability was for an orbit on February 2, 2002, with PVA 4B locked (see Figure 6). As in the previous comparisons, the qualitative agreement between measured and calculated values over the orbit Sun period was excellent. The RMS difference was 3.3A on the backside and 4.4A on the front side. Both front-illuminated and back-illuminated current values exhibit occasional small ripples

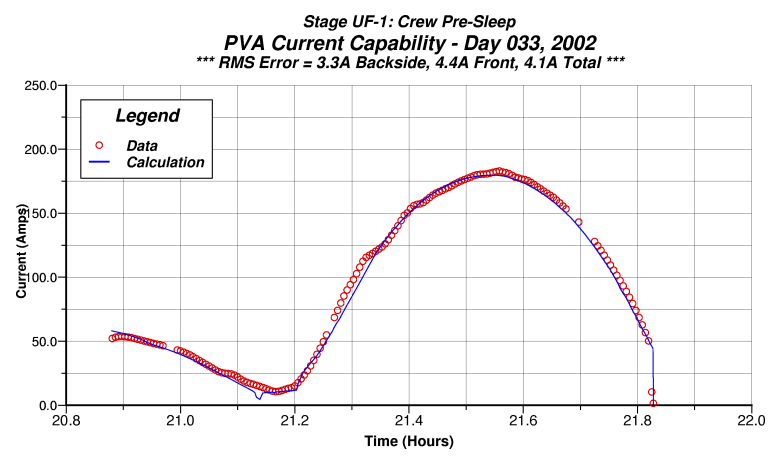

FIGURE 6. - COMPARISON OF PREDICTED AND MEASURED PVA CURRENT PRODUCTION CAPABILITY (FEBRUARY 2, 2002)

\section{DISCUSSION}

The above three data sets illustrate ISS PVA performance over a wide range of front side and backside solar illumination angles. The excellent agreement between measured and calculated PVA current values demonstrates the bifacial performance model is sound. However, minor discrepancies in the comparison did exist for portions of the data. These differences are explained qualitatively in the paragraphs that follow.

In all three comparisons, current was over predicted $10 \%$ to $15 \%$ at the start of the Sun period. At this point in the orbit, the PVA operating temperature is approximately $-80{ }^{\circ} \mathrm{C}$. At this temperature, the bandgap of crystalline solar cells increases and the solar cell spectral response (front and back sides) is diminished in the red and infrared part of the spectrum. During PVA back illumination, sunlight must pass through the polyimide substrate which filters short wavelengths, but allows longer wavelengths to pass. Thus, the red-dominated backside PVA current production is much more sensitive to the cold, post-eclipse operating temperatures than PVA front illuminated current production. In the computational model, solar cell temperature coefficients are employed to account for temperature-dependent current-voltage performance. These coefficients were derived from front-illuminated cell flash test data and do not properly account for the red-shifted, back-illuminated solar cell performance temperature dependence. Thus, very cold $\left(-80^{\circ} \mathrm{C}\right)$ back-illuminated PVA currents will be over-predicted. However, the lightweight PVA warms quickly and is at $0^{\circ} \mathrm{C}$ within $\sim 3$-minutes following orbit sunrise. Therefore, the error introduced in the total amp-hours produced by the PVA over an orbit Sun period is very small.

A second discrepancy was that minimum PVA currents were over-predicted by about 5 -amps during near edge-on solar illumination conditions for mission days on December 10, 2001 (3-minute period of time at about 16.50 hours in Figure 4) and on April 12, 2002 (3-minute period of time at about 5.75 hours in Figure 5). For these short periods, PVA current was generated exclusively by albedo illumination. The most likely explanation for this was that the attached space shuttle orbiter and the FGB and Service Module PVAs were blocking a portion of Earth albedo flux that illuminated the US PVA front and back surfaces. This was determined by reviewing ISS flight attitude animations produced by SPACE. In SPACE, view factors to major ISS surfaces, including the $F G B$ and Service Module arrays, were calculated. The sum of these view factors were used in the PVA thermal model as a reduction in radiation view factor to deep space. Reduction in Earth radiation or Earth albedo fluxes were not included in SPACE. As such, diminished Earth albedo fluxes from ISS surface blockage were not modeled and would lead to a small over-estimation in PVA current. In contrast, PVA current nicely matched the data during near edge-on solar illumination on February 2, 2002 (time period near 21.15 hours in Figure 6). After reviewing the ISS flight attitude animation, it was clear that the view to Earth at this time was unobstructed by major ISS surfaces.

The last discrepancies were minor PVA current "ripples" observed for these mission days. Current ripples were characterized by the measured currents varying above and below the smooth predicted current profile over a several minute period of time. After reviewing the ISS attitude animations, it was clear these ripples coincided with special Sun angles on the ISS and space shuttle orbiter, if attached. On December 10, 2001 at about 16.2 to 16.4 hours 
(Figure 4), the Service Module PVA albedo flux to the 4B PVA front side was maximized. Later in the same orbit, around 16.6 to 16.9 hours, orbiter albedo to the 4B PVA backside was maximized followed by 4B PVA shadowing onto the orbiter (essentially eliminating orbiter albedo flux). The same orbiter albedo flux situation occurred late in the orbital sun period on April 12, 2002, at about 5.9 to 6.2 hours (Figure 5). Lastly, on February 2, 2002, at about 21.1 hours (Figure 6), the Service Module PVA albedo flux to the 4B PVA front side was maximized. Slightly later in the orbit, at about 21.3 hours, the Service Module and FGB module PVA albedo fluxes were maximized to the 4B PVA backside. The small current dip at 21.7 hours is due to a conservative application of array pointing error used in SPACE. The pointing error is applied in the direction that results in minimum power, which can cause large differences between SPACE and on-orbit data at high off pointing angles.

The impact of these spacecraft created albedo fluxes was to slightly increase measured PVA current output. Although the view factors to other ISS PVAs were calculated in SPACE, the view factor to the attached orbiter was not calculated. Since spacecraft view factors were not used to calculate spacecraft albedo fluxes onto the 4B PVA, calculated current output will be slightly underestimated for these brief periods of time when the ISS flight attitude and local Sun angle conspire to maximize spacecraft albedo.

\section{SUMMARY AND CONCLUDING REMARKS}

A computational model to predict ISS PVA electrical performance under generalized bifacial illumination conditions was developed. Telemetered PVA performance data for three different sample orbits over the period from December 2001 through April 2002 were obtained and reduced. A comparison of these data with calculated PVA performance revealed an excellent qualitative agreement. The RMS difference in measured and calculated PVA currents was well with in the $\pm 6 \%$ uncertainty in the PVA performance model. This indicated that the SPACE bifacial PVA performance model was sound. Minor discrepancies were noted in the comparison of calculated and telemetered PVA current data. The likely causes for these discrepancies were discussed.

The updates to this PVA performance model have increased its correlation with on-orbit data. With this more accurate modeling capability, improved power predictions that support on-orbit operations, certification for flight readiness, and mission planning can be made. The bifacial performance code developed by GRC has not only been incorporated in to SPACE, but is also incorporated in software used by the NASA Johnson Space Center Mission Operations Directorate for day-to-day on-orbit ISS operations planning. Since the authors' first paper on this matter (Delleur, Kerslake, et al., 1999) the space station program office has come to rely on the power produced from the PVA backside for on-orbit operations and planning.

\section{REFERENCES}

Bordina, N.M., Zayavlin, V.R., Kagan, M.B. and Letin, V.A., "Solar Batteries With Bifacial Sensitivity," Geliotekhnika, Vol 28, No 1, 1992, p. 39-47.

Delleur, A.M., Kerslake, T.W., Scheiman, D.A. "Analysis of Direct Solar Illumination on the Backside of Space Station Solar Cells," NASA/TM—1999209377, July 1999. $34^{\text {th }}$ IECEC, Vancouver, B.C., August 1-6, 1999.

Fincannon, J., Delleur, A., Green, R.D., Hojnicki, J.S., "Load-Following Power Timeline Analyses for the International Space Station," NASA TM-107263, $31^{\text {st }}$ IECEC, Washington D.C., August 11-16, 1996.

Fincannon, H. James, "Comparison of ISS Power System Telemetry with Analytically Derived Data for Shadowed Cases," paper no. 20113, $37^{\text {th }}$ IECEC, Washington D.C., July 28-August 1, 2002.

Hashmi, Abida T., "Space Station Freedom Solar Array Development Testing," $28^{\text {th }}$ IECEC, Atlanta, GA, Aug 8-13, 1993, paper 93449, p. 1.365-1.370.

Hojnicki, J.S., Green, R.D., Kerslake, T.W., McKissock, D.B., Trudell, J.J., "Space Station Freedom Electrical Performance Model," NASA TM106395, 28 ${ }^{\text {th }}$ IECEC, Atlanta, GA, August 8-13, 1993.

Jannette, A.G., Hojnicki, J.S, McKissock, D.B., Fincannon, J., Kerslake, T.W., Rodriguez, C.D., "Validation of International Space Station Electrical Performance Model via On-Orbit Telemetry," 37th Intersociety Energy Conversion Engineering Conference, Washington, DC, Jul 28-Aug 1, 2002. Josephs, R. H., "Solar Cell Array Design Handbook," NASA CR-149364, Oct 1976.

Kerslake, T.W. and Hoffman, D.J., "Mir Cooperative Solar Array Flight Performance Data and Computational Analysis," NASA/TM—1997-107502), July 1997.

Kerslake, T.W. and Hoffman, D.J., "Performance of the Mir Cooperative Solar Array After 2.5 Years in Orbit," NASA/TM—1999-209287, July 1999.

Kerslake, T.W., Hojnicki, J.S., Green, R.D., Follo, J.C., "System Performance Predictions For Space Station Freedom's Electrical Power System," NASA TM-106396, $28^{\text {th }}$ IECEC, Atlanta, GA, August 8-13, 1993.

Lillington, D.R., Kukulka, J.R., Nasib, A.V., Sater, B.L. and Sanchez, J., "Optimization of Silicon $8 \mathrm{~cm} \mathrm{x}$ $8 \mathrm{~cm}$ Wrap through Space Station Cells for 'On Orbit' Operation," $20^{\text {th }}$ IEEE Photovoltaics Specialist Conference, Las Vegas, NV, September 26-30, 1988, p. 934-939.

Vogt, S.T. and Proeschel, R.A., "Space Station Photovoltaic Power Module Design," $23^{\text {rd }}$ IECEC, Denver, CO, Jul 31-Aug 5, 1988, paper 889101, p. $567-572$. 
Public reporting burden for this collection of information is estimated to average 1 hour per response, including the time for reviewing instructions, searching existing data sources, gathering and maintaining the data needed, and completing and reviewing the collection of information. Send comments regarding this burden estimate or any other aspect of this collection of information, including suggestions for reducing this burden, to Washington Headquarters Services, Directorate for Information Operations and Reports, 1215 Jefferson Davis Highway, Suite 1204, Arlington, VA 22202-4302, and to the Office of Management and Budget, Paperwork Reduction Project (0704-0188), Washington, DC 20503.

\begin{tabular}{|l|c|c|}
\hline 1. AGENCY USE ONLY (Leave blank) & $\begin{array}{c}\text { 2. REPORT DATE } \\
\text { July } 2002\end{array}$ & $\begin{array}{r}\text { 3. REPORT TYPE AND DATES COVERED } \\
\text { Technical Memorandum }\end{array}$
\end{tabular}

\section{TITLE AND SUBTITLE}

\section{FUNDING NUMBERS}

Electrical Performance of the International Space Station U.S. Photovoltaic Array During Bifacial Illumination

6. AUTHOR(S)

Ann M. Delleur and Thomas W. Kerslake

\section{PERFORMING ORGANIZATION NAME(S) AND ADDRESS(ES)}

National Aeronautics and Space Administration

John H. Glenn Research Center at Lewis Field

Cleveland, Ohio 44135-3191

\section{SPONSORING/MONITORING AGENCY NAME(S) AND ADDRESS(ES)}

National Aeronautics and Space Administration

Washington, DC 20546-0001
WU-575-15-69-00

8. PERFORMING ORGANIZATION REPORT NUMBER

E-13476

\section{SUPPLEMENTARY NOTES}

Prepared for the 37th Intersociety Energy Conversion Engineering Conference sponsored by the Institute of Electrical and Electronics Engineers, Electron Devices Society, Washington, DC, July 28-August 2, 2002. Responsible person, Ann M. Delleur, organization code 6920, 216-433-5519.

Unclassified - Unlimited

Subject Category: 20

Distribution: Nonstandard

Available electronically at http://gltrs.grc.nasa.gov/GLTRS

This publication is available from the NASA Center for AeroSpace Information, 301-621-0390.

\section{ABSTRACT (Maximum 200 words)}

With the first United States (U.S.) photovoltaic array (PVA) activated on International Space Station (ISS) in December 2000, on-orbit data can now be compared to analytical predictions. Due to ISS operational constraints, it is not always possible to point the front side of the arrays at the Sun. Thus, in many cases, sunlight directly illuminates the backside of the PVA as well as albedo illumination on either the front or the back. During this time, appreciable power is produced since the solar cells are mounted on a thin, solar transparent substrate. It is important to present accurate predictions for both front and backside power generation for mission planning, certification of flight readiness for a given mission, and on-orbit mission support. To provide a more detailed assessment of the ISS power production capability, the authors developed a PVA electrical performance model applicable to generalized bifacial illumination conditions. On-orbit PVA performance data were also collected and analyzed. This paper describes the ISS PVA performance model, and the methods used to reduce orbital performance data. Analyses were performed using SPACE, a NASA-GRC developed computer code for the ISS program office. Results showed a excellent comparison of on-orbit performance data and analytical results.

\section{SUBJECT TERMS}

International Space Station; Power generation; Backside illumination; Performance modeling; Solar cell performance; Bifacial illumination

\begin{tabular}{|c|c|c|}
\hline $\begin{array}{c}\text { 17. SECURITY CLASSIFICATION } \\
\text { OF REPORT } \\
\text { Unclassified }\end{array}$ & $\begin{array}{c}\text { 18. SECURITY CLASSIFICATION } \\
\text { OF THIS PAGE } \\
\text { Unclassified }\end{array}$ & $\begin{array}{c}\text { 19. SECURITY CLASSIFICATION } \\
\text { OF ABSTRACT } \\
\text { Unclassified }\end{array}$ \\
\hline
\end{tabular}

15. NUMBER OF PAGES

12

16. PRICE CODE

\section{LIMITATION OF ABSTRACT}



